\title{
THE POLITICAL DYNAMICS OF THE LAND AND GROWTH MANAGEMENT MOVEMENT*
}

\author{
John M. DeGrove†
}

I

\section{Land and Growth Management \\ in the Federal System}

The allocation of authority and responsibility by government level is a crucial question in any federal system. The issue is never settled since changing conditions and demands have an impact on which level of government does what. ${ }^{1}$ In a strict legal sense, the U.S. federal system is composed of two levels-the federal government and the states. As a matter of political reality, there is a three-tier federal system composed of the federal, state, and local levels. While governments are legally creatures of the state, they have emerged as strong political forces in the federal system. Any understanding of the United States system requires an understanding of how power has shifted among the three tiers over the nation's 200-year history.

Historically, research on the U.S. federal system has concentrated on a legal definition of what level of government should carry out what responsibility in that system. The issue tended to be defined in terms of absolute allocations of authority to one level or another and the courts played an important role in attempting to apply neat, simplistic solutions to a complex and interrelated problem. Scholars who studied the federal system often attached the "dual" or "competitive" adjective to this approach and in their own work contributed to largely unsuccessful efforts to allocate authority and responsibility between the federal and state levels. More recently, a "revisionist" approach to the theory of federalism was given major emphasis by Morton Grodzins. Grodzins and his followers made it clear that the notion of a neat separation of authority by level of government for the performance of major functions was not, and had never been, a characteristic feature of the U.S. federal system. They asserted and documented the proposition that from the beginning

* The author acknowledges a grant from the Kettering Foundation which supported the collection of much of the data on which this paper is based. The full results of that research will be published in 1980.

$\dagger$ Director, Joint Center for Environmental and Urban Problems, Florida Atlantic and Florida International Universities.

1. For a classic statement of the forces that come to bear in the distribution of authority in a federal system, see K.C. Wheare, Federal Government (1946). 
we had a system of shared powers in which all levels of government participated in every major functional activity. ${ }^{2}$

The political implications of the shared powers system in a federal government are great. The system carries the certainty that considerable tension will exist at any given time as to what part of what major function should be performed by what level of government. These disputes have been characteristic of the politics of federalism in the United States, and the arguments, while often set in a narrow legal framework, have in fact involved important substantive policy issues about where and how major power would be exercised by governments in the federal system. This tension has been characteristic of the land and growth management area and has become a major focus in the last decade.

States have always held most of the ultimate power over land use and growth management, but until recently were content to delegate this politically volatile issue (centered on zoning) to local governments. From the beginning of zoning law development in the United States (shortly after the turn of the century) the bulk of the efforts to manage and control land occurred at the local level. The major vehicle for this control was traditional zoning approaches. States, except for the enactment of enabling legislation of one kind or another, tended to stay clear of this issue. ${ }^{3}$

National government activism in this field also was not characteristic of the system until recently. The exclusive local government role in this area, however, has given way since World War II, especially in the last decade, to major initiatives by federal and state governments. While Congress has not enacted a general land use law, it has taken major actions that directly and indirectly affect the land use area. One count identified over 100 programs that had an impact on land and growth management. ${ }^{4}$ Such actions as the Comprehensive Planning Assistance Grant Program (701), ${ }^{5}$ the Rural Development Program, ${ }^{6}$ and the 1972 Coastal Zone Management Act $^{7}$ constitute examples of direct efforts to produce desired land and growth management results at state and local levels through federal grant programs. Major regulatory programs include the federal Water Pollution Control Act as amended in $1972,{ }^{8}$ the Clean Air

2. A more comprehensive overview of the concept of shared powers can be found in $M$. Grodzins, The Federal Sustem, in The American Assembly, Goals for Americans Today (1960); M. Grodzins, The American System: A New View of Government in the United States (1966); and D.J. Elazar, American Federalism: A View from the States (1972). Elazar was a student of Grodzins and has continued to do major work in this field.

3. National Commission on Urban Problems, Building the American City, at 192-201 (1969).

4. Council of State Governments, Land: State Alternatives for Planning and ManageMENT $19(1975)$.

5. The Comprehensive Planning Assistance Program was first established by The Housing Act of 1954 .

6. 42 U.S.C. $\$ 3122(1970)$.

7. 16 U.S.C. $\$ \$ 1451-64$ (Supp. V 1975).

8. 33 U.S.C. \$§ $1251-1376$ (Supp. V 1975). 
Act, ${ }^{9}$ and the Noise Control Act. ${ }^{10}$ This legislation, and many additional acts not listed, constitute a major federal entry into the land and growth management area that has implications for the allocation of power among levels of government in the federal system. Whether or not it means an automatic weakening of the state and local role in land and growth management depends on what happens in terms of added activity in this area at those levels of government. ${ }^{11}$

The emergence of the state as a major actor in land and growth management is more recent than that of the federal government. Beginning with Hawaii in 1961, perhaps a dozen states have taken major actions in asserting or reasserting their authority in land and growth management. This role by state governments, in its political context, will be the focus of this paper. This is justified in view of the critical role state governments play as the middle level of the federal system. Furthermore, any hope of rationalizing land and growth management systems by sub-state regions and in states as a whole depends on a strong policy and management framework articulated from the state level.

This state framework can and should accomplish two policy objectives. One goal involves simplifying and coordinating land and growth management controls to avoid undue burdens on the private sector. The second objective concerns the exclusionary issue, which has two important dimensions. In a negative sense, states can prescribe growth management policies that prevent overt exclusionary actions by local governments in the process of designing and implementing land and growth management systems. Perhaps more importantly, states can require actions that can lead to the design and implementation of regional fair share housing programs aimed at assuring the availability of low and moderate income housing when and where it is needed. In short, the state has the power, the geography, and the resources to take the lead in policy initiatives in the land and growth management area.

The assertion by the state of a stronger role in the land and growth management area can be seen as part of a broader trend in which two major forces act on the federal system simultaneously. In the first place, modernized state constitutions across the nation grant broader and stronger home rule powers to cities and counties. In theory this action alone would produce a strengthening of the local level in the federal system. However, activist state legislatures have accompanied this grant of home rule power with stronger state initiatives that, in some cases, have preempted any exclusive power base for local governments. Perhaps the most significant example of this state reas-

9. 42 U.S.C. $\& 1857$ (1970 \& Supp. V 1975).

10. 42 U.S.C. $\S \S 4901-18$ (Supp.V 1975).

11. Council of State Governments, Land: State Alternatives for Planning and ManAgement, supra note 4; J.M. DeGrove, Land Management: New Directions for the States, in UrBaN Options I (A.K. Campbell ed. 1976). 
sertion of authority is in land and growth management, but it is by no means the only one that could be cited. ${ }^{12}$

If states are asserting a stronger role in their relationship with local governments in the federal system, it is also true that many are demanding stronger positions vis-à-vis the federal government in that system. Thus, we have a federal system changing substantially in the land and growth management area. The stronger federal role in land and growth management has been accompanied, or at least was followed by, an assertion of authority by state governments. Simultaneously, local governments increased their activity in land and growth management, some in major ways. Thus, the land and growth management situation has not involved one level of government taking power away from another level; all three government levels have expanded their authority. The politics of this expansion, with a focus on state government, is the focus of this article. We will examine the politics of state involvement in land and growth management by outlining the politics of gestation, adoption, and implementation of state initiatives. We will assess the impact of state action on the federal system, and on changing state and local relations. Finally, we will gauge what could happen in future land and growth management. We will focus on three states to illustrate a range of approaches involving major state initiatives in land and growth management. ${ }^{13}$

The states analyzed will be: Florida, which passed a major land use initiative in 1972; California, where a major land use law was initiated directly through citizens in 1972 and reinforced by state legislative action in 1976; and Oregon, where a major land use bill was passed in 1973. These states represent positions on a state land use initiative continuum ranging from a general assertion of state authority (Oregon); to strong assertion of state control in a particular geographical area, the coast (California); and finally, to a strong, but selective, application of state land use powers throughout a state (Florida).

\section{The Environmental Roots of Political Support for Land and Growth Management}

The origin and major sources of support of what has been called the "new mood" in land and growth management form a backdrop for political assessment of the movement. While many factors can be cited as contributing to the

12. DeGrove. Analysis of Home Rule and Intergovernmental Relations: The Case of Florida, in Partinership Within the States: Local Self-Government in the Federal System, at 146-48 (S. Cole ed. 1976).

13. Growth management, as it is used in this paper, is a broader term than land management, and includes all elements typically encompassed by a comprehensive plan, including the economic, social and physical aspects of land and growth management. The major expression of growth policy and growth management to date in the United States has been through new initiatives in the land management area. 
development of greater concern by all levels of government for growth management, the most critical source of support has been the rising concern of Americans for their environment. Historically, U.S. citizens have associated progress with growth. This association has been criticized severely in recent years, particularly within the last decade. ${ }^{14}$

The environmental movement undergirds changing attitudes toward land use and continues to lend to land and growth management much of its sustaining political strength. Below, we will analyze the problems that have spurred this new attitude in Oregon, California and Florida. Generally, environmental groups and their increasingly broad-based allies have been concerned with the degradation of our land, air and water resources, and they have increased their concern with the "more than local" impact of many federal, state and local land use decisions. The chronic overloading of waste water treatment plants, the inability to deal effectively with solid waste, the wholesale destruction of biologically critical wetlands, and in a more general way, the destruction of the flora and fauna of our natural systems have combined to create a genuine sense of crisis among environmental groups. Such groups, in turn, have often found themselves moving from a posture of futile protest to the center of political power. ${ }^{15}$

The policy response to the growing strength of the environmental forces outlined above has not been confined to the federal and state levels. Some of the more dramatic efforts to manage growth have occurred at the local level. These efforts have included the establishment of population ceilings (Boca Raton, Florida has its so-called dwelling unit cap of 40,000); the blanket denial of development (illustrated at one time by Loudoun County, Virginia); and the increasingly popular staged growth technique that is associated with the town of Ramapo (Rockland County), New York. Another version of the staged growth approach, equally well-known, occurred in the community of Petaluma, California, north of San Francisco. All of these approaches, in one way or another, sought to stop or slow growth in the name of preventing environmental degradation, and more generally degradation of the quality of life in the community imposing the controls. While important legal questions are raised by such actions, the record in the courts to date suggests that

14. F. Bosselman \& D. Callies, The Quiet Revolution in Land Use Control (1972) and W.K. Reilly, The Use of Land: A Citizen's Policy Guide to Urban Growth (1973) are only two of the many publications illustrating the new mood.

15. The increasing strength of the environmental movement as a major force in the political system is not only illustrated by the success of the movement in pushing major new action at the federal, state and local levels, but is confirmed by important surveys that have attempted to measure the attitude of the public toward environmental matters. One such study was Florida Defenders of the Environment, Environment and Florida Voters, Work Paper No. 7 (Gainesville, Fla., Urban and Regional Development Center, Univ. of Fla.) (1974). Another study, one of a series by the Gallup poll organization, reported by George Gallup at the National Conference on Managed Growth held in Chicago on Sept. 16, 1973, also supported the proposition that the strength of the environmental, and more broadly the quality of life, movement was very great. 
growth management efforts at the local level that are crafted carefully and carried out in an even-handed way, can be sustained in the courts. ${ }^{16}$ In stressing the impact of growth on the "quality of life," moreover, such efforts go well beyond environmental concerns in the natural systems sense and embrace concerns about overloaded transportation systems; the loss of open space (especially beaches and shore areas); the esthetic outrages occasioned by shoddy or poorly planned growth; and general feelings of "too much" and "too many." Persons embracing the view that "I'm here and now we have enough" can and do make common cause with others primarily concerned with natural systems to support growth management efforts. Both groups are accused often of supporting growth management schemes that have an exclusionary impact, and, in some cases, this does seem to be the case. On the other hand, a local land and growth management system, especially one developed within a state policy framework sensitive to the issue, can lead to more attention to low and moderate income housing needs. In any event, concern for the negative impacts of growth that goes beyond concern for the physical environment adds to political support for land and growth management efforts.

The question of how deep are the roots of the new attitude toward land and growth management is a critical one in assessing the politics of the future in this area. If environmental groups still could be characterized as shrill "bird and bee nuts" clamoring for an end to all growth and absolute protection of all natural things, there would be little reason to suspect that their political strength could be sustained. Such description, while it may have been accurate in part at one time, no longer reflects the realities of power in growth management politics. The fact is that the relatively narrow base of environmental pressure groups that characterized the forties and fifties in the United States expanded substantially in the sixties and seventies. The focus on the physical aspects of the environment, furthermore expanded to a broader concern for something called "the quality of life."

A typology of state involvement in land use from weak to strong would find all three of the states analyzed falling in the strong involvement category. However, each state-California, Oregon, and Florida-represents a substantially different approach to state action in the land use area. Our purpose is to analyze each state in terms of the politics of gestation, the politics of adoption, the politics of implementation, and the politics of the future. Politics

16. For a more detailed report on local government initiatives in the land and growth management area, see 2 Management and Control of Growth: Issues, Techniques, Problems and Trends chs. 10-11 (R. Scott, D. Brower, \& D. Miner eds. 1975). For a full discussion of some legal issues involving land and growth management, see F. Bosselman, D. Callies \& J. Banta, The Taking Issue: An Analysis of the Constitutional Limits of Land Use Control (1973) (prepared for the Council on Environmental Quality). Recent case law is explored id. at 141-94. For a somewhat different approach to the taking issue see D. Hagman \& J. Miscznski, American Society of Planning Officials, Windfalls for Wipeouts (1978). 
of gestation can be defined as the development of problems and issues that were perceived by groups and individuals to demand strong state action in the land use area-the issue base for action. By the politics of adoption, we mean those governmental and private forces that opposed or supported the approval of a strong state action in the land use area. Politics of implementation means major political developments during the period in which new land use laws were being carried out. The continuing role of the legislature, the governor, and the major interest groups are included in this category, as are major efforts to strengthen or weaken the originally adopted legislation. Finally, we will examine briefly the politics of the future in an effort to anticipate what will happen with regard to state initiatives in growth and land use in the next decade.

\section{III}

The Politics of Land and Growth Management:

A Focus on the States

A. The Politics of Gestation and Adoption

\section{Florida}

In explosive post-World War II growth, the state's population expanded from 2,771,305 (1950) to 6,791,000 (1970) and subjected the Florida environment to negative impacts, ranging from extensive water pollution and water supply shortages to the closing of access to public beaches and the widespread destruction of wetlands. The state's response to severe droughts in 1970 and 1971 was to convene what proved to be a historic Governor's Conference on Water Management in South Florida. The conference was fired by Governor Reubin Askew's tough keynote address, through which he became the first state-elected official to question the intrinsic "goodness" of Florida's growth; 150 state citizens assembled and debated Florida's land and water management problems for three days. The conference produced a set of short, but far-reaching, policy recommendations that called for development of a state framework incorporating a state-regional-local partnership aimed at managing Florida's growth in order to balance the legitimate needs of growth with the equally legitimate needs to protect the state's environment.

The Governor responded to the conference report by appointing a fifteen member "Task Force on Land Use," and charged the group with producing legislative proposals to implement the Conference recommendations. Beginning in the fall of 1971 , and continuing into the winter and spring of 1972 , the task force presented four major bills to the legislature. We are concerned with the bill that became the 1972 Environmental Land and Water Management Act (LWMA). ${ }^{17}$ The Act's starting point was the Model Land Develop-

17. Fla. Stat. AnN. $\S 380-80.11$ (West Supp. 1978) [hereinafter cited as the Land Management Act]. 
ment Code draft that had been in preparation for a number of years by the American Law Institute. The bedrock of this approach was to leave the bulk of land use decisions in the hands of local governments, singling out certain "more than local impact" actions for special treatment involving state and regional review of local government action.

The process of passing the 1972 LWMA combined a coming of age for Florida's environmental groups, the skilled leadership of a governor determined to see the bill passed, and high quality post-reapportionment legislative leadership in the House and the Senate. Support for the legislation was bipartisan, with a significant Republican minority heavily supporting the proposed law. The strategy in passing the legislation was to strike quickly and pass it in the 1972 session, thus defying a Florida legislative tradition of weighing any controversial legislation several sessions before passage. The critical problem was to get the legislation through the Senate; the House speaker had the votes to pass the bill if it could clear the Senate. Opponents were organized poorly because of an early conviction that the bill had little chance of passing. They mounted a last ditch effort to send it to a study committee for the future or to kill it outright. They came close to success, but in the end the legislation cleared the Senate, went to the House, and was passed, during an extension of the regular session. Real estate and industrial development lobbyists led the opposition while city and county organizations remained neutral. The League of Women Voters worked effectively with environmental groups to mobilize public support. One major land developer broke ranks and supported the legislation.

On balance, passage of the law was a surprise to both its supporters and opponents. The new legislation involved a special state and regional review role for two types of land use actions: "areas of critical state concern" and "developments of regional impact." The major compromises made in getting the legislation passed involved limiting the total amount of the state's land that could be designated as an "area of critical state concern" to 5 percent at any given time (about 1.8 million acres); removing authority for interim controls in critical areas while regulations were being developed; placing the state override of local governments in the hands of elected officials instead of an appointed commission; and delaying implementation of certain parts of the legislation until the legislature could act on "developments of regional impact" criteria and the voters could act on a proposed Environmentally Endangered Lands bond issue of $\$ 200$ million (to reassure some legislators that funds would be available for outright land purchases if regulation could not do the job).

"Areas of critical state concern" were geographic (such as environmentally sensitive lands) and historical or archaeological sites of regional or state importance. State action was initiated directly in such areas and spelled out 
TABLE I

Florida: Growth Management Regulations

Environmental Land and Water Management Act of 1972

STATE:
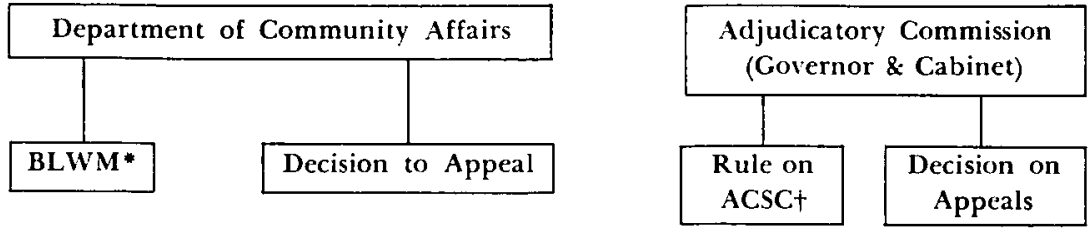

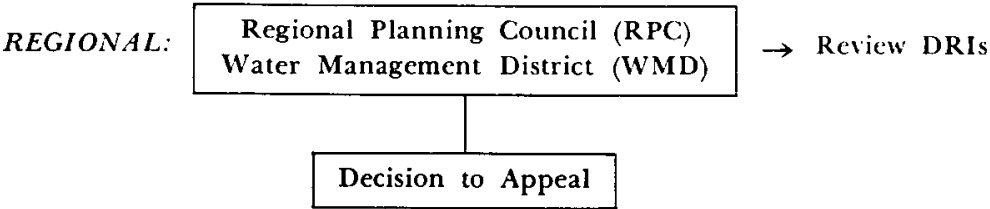

LOCAL:

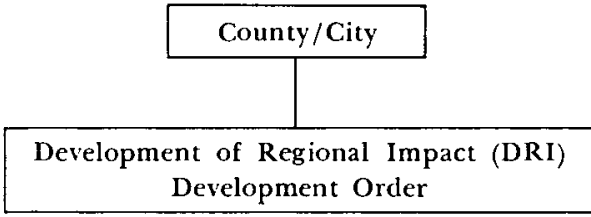

* BLWM: Bureau of Land and Water Management

+ ACSC: Area of Critical State Concern

the criteria that must be applied by local governments to their own land use regulations. Local governments would implement the state-approved regulations, subject to injunctive state action for failure to comply with standards. "Developments of regional impact" involved a project concept, such as large housing developments; airports; mining operations; large shopping centers; or large recreational and educational facilities. ${ }^{18}$

18. The author chaired the Governor's Task Force that drafted the legislation. Data in this Section are based mainly on direct participation in the process and subsequent interviews with other participants, as well as other sources such as an excellent master's thesis by J.W. May, The Florida Environmental Land and Water Management Act of 1972: Planning and the State Legislative Policy Making Process (1974) (unpublished thesis in Florida State University library). See also DeGrove, supra note 11 , at 138-40. For the full text of the ALI Code, see ALI, Model Land Development Code, Tentative Draft No. 3 (1971). 


\section{California}

The importance of the coast in California life is difficult to overestimate. The 1,100 miles of coastline are organized into fifteen counties. These coastal counties contained over thirteen million people in 1975 (63 percent of the state's population). Eighty-five percent of the California population lives within a one hour drive of the coast. Thus, the major social, economic, and political life of California is concentrated in coastal areas. In this sense California is comparable to Florida. Concern with the California coast as a valuable resource dates to the $1930 \mathrm{~s}$, but between 1931 and 1964 (when California's population grew from 5.5 million to over 18 million) little effort was made to develop a strong planning and management program for the coast. Beginning about 1964, efforts to protect the coast gained strength, encouraged by the creation of the San Francisco Bay Conservation and Development Commission as a temporary body in 1965 and as a permanent regulatory agency for San Francisco Bay in $1968 .^{19}$

The problems along California's coast covered almost the entire range of possibilities in the environmental degradation area. Population pressures were expressed in urban sprawl, air and water pollution, barriers to public access (which became the key battle cry in the fight to pass legislation), the destruction of marine life, the erosion of sandy beaches, the destruction of large areas of wetlands, and ocean pollution through sewage outfall systems. These and many other negative impacts became increasingly evident in the sixties and early seventies in California. ${ }^{20}$

Environmental groups reached new levels of strength in California in the early seventies. They used that strength to attract new allies and to make a major effort to pass a coastal management bill through the California legislature. In spite of a strong effort and consistent success in the House, efforts to push a bill through the Senate failed successively in 1970, 1971, and 1972. Steadily growing in strength, but frustrated by what they considered a Senate controlled by old guard special interests, environmental groups formed into the California Coastal Alliance in an effort to bypass the legislature and enact the legislation directly, and went directly to the people through the "initiative process." They were successful in a whirlwind campaign. Proposition $20,{ }^{21}$ the California coast initiative proposal (so named because of its position on the ballot), carried by 800,000 votes ( 55 percent of all votes cast). Support was

19. J. Adams, Proposition 20-A Citizen's Campaign, 1973 Syracuse L. Rev. 1021-22.

20. See Douglas \& Petrillo, California's Coast: The Struggle Today-A Plan for Tomorrow (I), 4 Fla. St. U. L. Rev. 179-84 (1976); Adams, supra note 19, at 1022-23; and R. G. Healy, LANd USE AND THE STATES 64-69 (1976).

21. California Coastal Zone Conservation Act of 1972 [hereinafter cited as the 1972 Coastal Act]. Cal. Pub. Res. Code $\S \S 27000-27650$ (West Supp. 1975), repealed by $\S 27650$, Initiative Measure (1972). 
TABLE II

\section{California}

1972 Constal Zone Conservation Act

STATE:

State Coastal Commission (6 Public, 6 Regional Members)

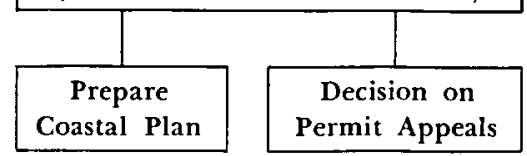

REGIONAL:

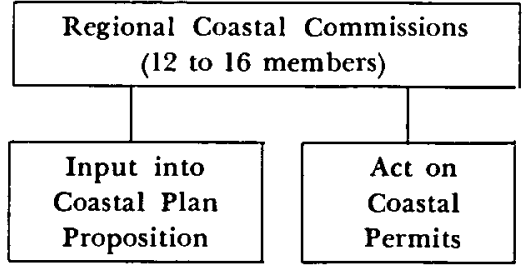

1976 California Coastal Act

STATE:

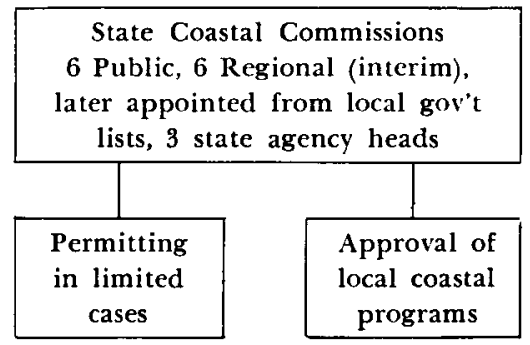

REGIONAL:

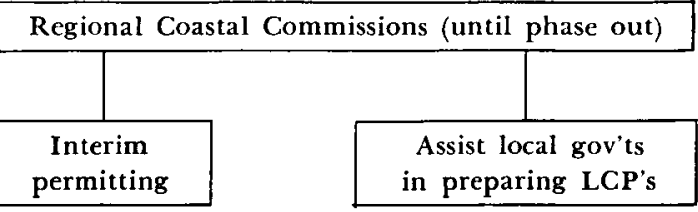

LOCAL

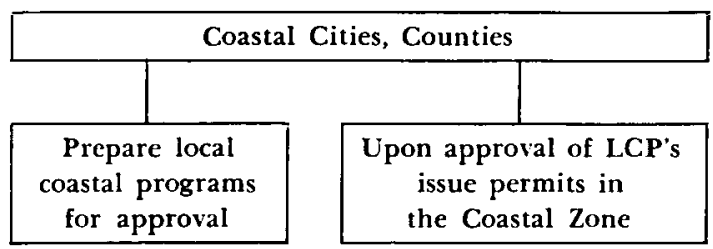


stronger in urban than in rural and undeveloped areas, especially along the sparsely populated northern coast.

The law passed by this remarkable expression of citizen interest established the California Coastal Zone Conservation Commission (the "State Commission") and six regional commissions. The new bodies had two important, distinct, though closely related tasks. First, the State Commission and its regional arms were directed to prepare a California coast plan spelling out how it should be managed in the long run. In the interim, a permitting system would be in effect essentially regulating all activity from the three mile territorial limit seaward to a thousand yards from the mean high water line landward. The State Commission was a twelve-member body composed of an equal number of representatives of the public and the regional commissions. Public members were selected by the Governor, the Speaker of the Assembly, and the Senate Rules Committee. Each appointing body named two members to the State Commission and each of the six regional commissions selected from among its own membership one member to serve on the Commission.

Proposition 20 was a "self-destruct" piece of legislation. The law would cease to exist shortly after the 1976 legislative term unless new legislation had been adopted in the meantime in response to the State Commission's presentation of the mandated coastal plan to the legislature. The interim permitting activity was broad in scope and required a permit for almost every type of development within the thousand yard limit. The permit applications would be judged against standards that were broad and rather flexible, and thus, much discretion was left to the state and regional commissions. A very liberal appeals procedure was provided which allowed citizens and environmental groups the right to appeal decisions of the regional commission to the State Commission. ${ }^{22}$

The passage of major land use legislation in California is unique among the states in its evolution from the direct initiative of the people. In both Florida, analyzed earlier, and Oregon, analyzed below, the initial legislation, though supported by similar political forces as in California, was passed by the state legislature.

22. California Coastal Act of 1976 [hereinafter cited as the 1976 Coastal Act], Cal. Pub. Res. CoDE $\$ \S 3000-3900$ (West 1977). For a detailed description of both the contents of Proposition 20 and the effort to win its adoption by the people of California, see both Douglas \& Petrillo, supra note 20, at 184-91; and Adams, supra note 19, at 1043-46 for a summary of the content of the 1972 law. See also R.G. HeAly, supra note 20, at 69-73 for comments on the passage and content of Proposition 20. Data for the above Sections were also taken from interviews by the author with Janet Adams, Peter Douglas and Norbert Doll in California (Dec. 1976). For the complete text of the California Conservation Act of 1972, see California Coastal Zone Conservation Commission, California Coastal Plan $431-34$ (1975). (The plan is available through the Documents and Publications Branch, P.O. Box 20191, Sacramento, Cal. 95820.) 


\section{Oregon}

The people of Oregon have an unusually strong affection for their wild and rugged coast, the pastoral features of a well-defined valley flanked by mountain ranges, and the wild sagebrush and timber areas of eastern Oregon. They look south to their California neighbors with dismay and vow not to let their Willamette Valley go the way of California's Santa Clara and San Fernando Valleys. The center of environmental concern in Oregon is not on the coast, but in the rich valley running some one hundred miles from north to south. It contains about 2,000,000 acres of flatland ideal for both agriculture and urban development. The pressure of urban encroachment on prime agricultural land has been heavy in recent years. The valley's population was about 1.5 million in 1970 and is projected to grow by a million in the next thirty years. By the early 1970s, Oregonians were alarmed; their concern was expressed by their colorful Governor Tom McCall in his opening remarks to the 1973 Legislature:

There is a shameless threat to our environment, ... and to the whole quality of life-[ that threat is] the unfettered despoiling of the land.

Sagebrush subdivisions. Coastal "condomania," and the ravenous rampage of suburbia in the Willamette Valley all threatened to mock Oregon's status as the environmental model for the nation.

We are in dire need of a state land-use policy, new subdivision laws, and new standards for planning and zoning by cities and counties. The interests of Oregon for today and in the future must be protection from the grasping wastrels of the land..$^{23}$

The move to put Oregon's land use law ${ }^{24}$ on the books took place within a relatively short time frame in the 1971-73 period and was preceded by a number of other important legislative actions in the 1960s. ${ }^{25}$ During this time the state was subjected to a kind of blitz in which powerful forces aligned themselves on both sides of the issue, an intense legislative struggle took place, many key compromises were made in terms of the originally drafted bill, and the legislation finally passed.

The key figure in passing Oregon's land use law in the legislature was a relatively new Senator, Hector Macpherson, who set about with extraordinary determination and persistence to achieve his treasured goal of putting a law

23. As quoted in C.E. Little, The New Oregon Trail 7 (1974). Other data from same source at 11-13; and from author's interview with Henry Richmond, Executive Director, Thousand Friends of Oregon, in Portland, Ore. (Sept. 9, 1976).

24. Oregon Land Use Law, Or. Rev. Stat. § 197 (1977).

25. Telephone interview with Gov. Tom McCall, in Portland, Ore. (Sept. 9, 1976); interview with Don Jones, Director, League of Oregon Cities, and Jerry Orrick, Executive Director, Association of Oregon Counties, in Salem, Ore. (Sept. 8, 1976); interview with Steve Schell, Vice Chairman, Land Conservation and Development Commission, in Portland, Ore. (Sept. 7, 1976). Action in the 1960s included: an open beaches law; a mandatory deposit on beverages statute; a stronger fill and removal bill; and Senate Bill 100, a statute mandating a preparation of a comprehensive land use plan by cities and counties, the direct precursor of the 1973 law. 
TABLE III

ORECON

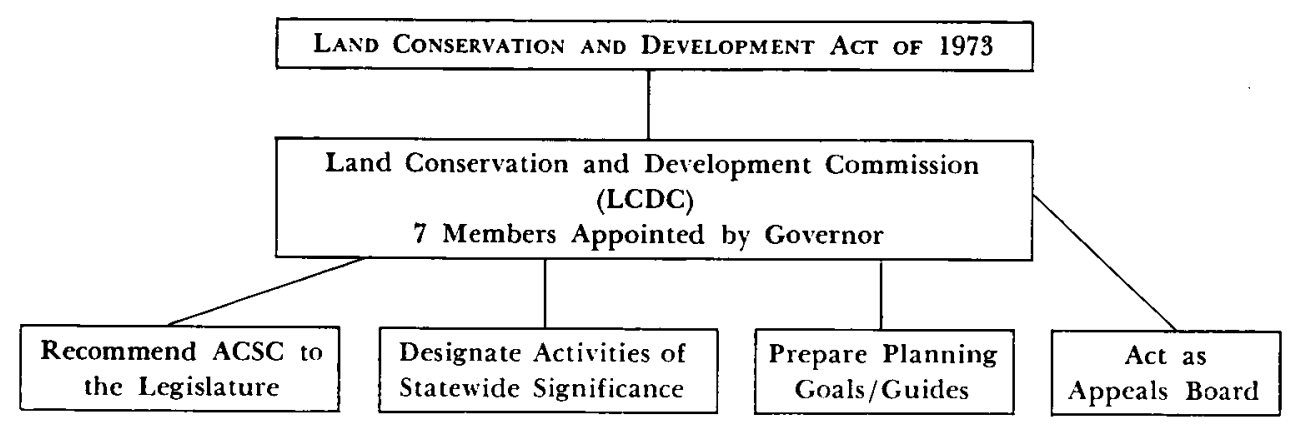

Comprehensive Plan

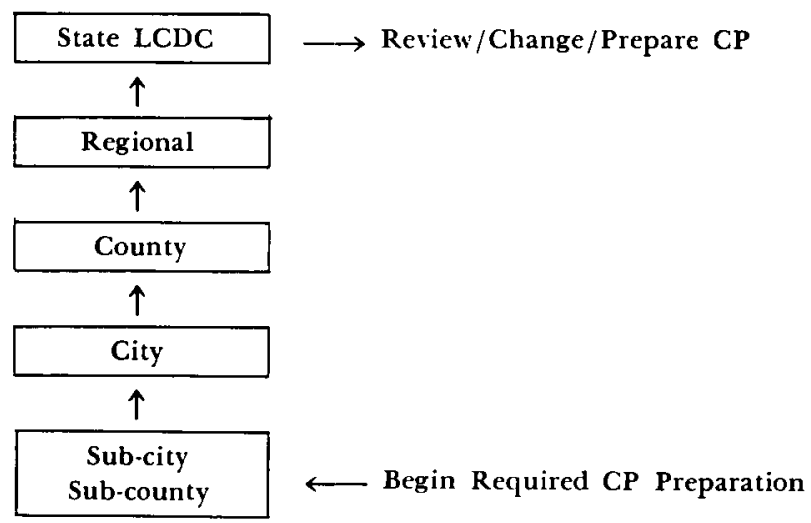

on the books that would better regulate the use of land in Oregon. Macpherson was a farmer, but his hopes for land use in Oregon went beyond the protection of agricultural land. Elected to the legislature in 1971, he moved immediately to set up a group to develop a land use bill for the 1973 session. He was unsuccessful in his efforts to get support from the senate leadership, but, working with environmental groups and Governor McCall, he put together an ad hoc study group whose members represented many key power groups in Oregon. Included on the committee were representatives from the Oregon Association of Industries, the State Homebuilders Association, local government, Portland area business leaders, and environmental 
groups. The ad hoc committee worked through a number of proposed drafts from 1971 to 1973 and was ready to propose a bill to the 1973 Legislature. ${ }^{26}$

The critical Oregon Legislature problem (as was the case in Florida and California) was the Senate in general and a Senate committee in particular. The key question was whether any bill could be brought from the Senate Environmental and Land Use Committee, on which Hector Macpherson sat, but which he did not chair. Macpherson noted that at the beginning of the session there were only three "sure" votes (including his own), on a seven-person committee. He described the remaining committee members as "pretty conservative." Efforts at compromises to allow the proposed legislation to clear the committee failed and Macpherson returned to the ad hoc committee technique, supported by the Governor and the Senate leadership. With close participation by a representative from the Governor's office, a group of key non-legislators (many of whom had served on Macpherson's interim ad hoc committee earlier) was put together.

The ad hoc group included: representatives from counties; limited representation from environmentalists (since they were not the problem); representatives from the Oregon Association of Industries and one of Oregon's two leading timber companies, Weyerhaeuser; as well as a representative of the Governor's office for liaison and technical support. The chairman of the committee was L. B. Day, a former Oregon legislator and former appointee of Governor McCall to head an environmental agency. Day was serving then as the head of the Teamsters Union in the State of Oregon. He was and is a brusque, outspoken, but generally highly respected, individual; and he set to work with his characteristic vigor and enthusiasm to hammer out a bill that would pass. As Day himself recalled it, the problem was "how to breathe life into a dead bill."27

A series of key compromises retained a coordinating, standard-setting, and review role for the state, eliminated a general role for the regional level, and removed the power of the proposed state land use commission to designate and require permits for developments within the "areas of critical state concern." With the compromises, the bill was pushed through the Senate. The house concurred, though a majority there probably wanted a stronger bill, and Oregon's historic land use law cleared the legislature.

In summing up the politics of adoption, one must say that the two major factors in the adoption were the tenacity of Senator Macpherson in persisting when the cause looked hopeless and the strong, consistent support of Governor McCall. The passage of the legislation did not involve partisan politics.

26. Interview with Hector Macpherson, former State Senator, in Portland, Ore. (Sept. 7, 1976); and interview with Steve Schell, in Salem, Ore. (Sept. 8, 1976).

27. Interview with L.B. Day, Chairman, Land Conservation and Development Commission, in Salem, Ore. (Sept. 8, 1976); and interview with Hector Macpherson, in Portland, Ore. (Sept. 9, 1976). 
Strong support came from both parties; however, voting on the legislation broke sharply along geographical lines. Willamette Valley legislators voted five-to-one in favor of the legislation (forty-nine-yes, nine-no, with two abstentions), while the thirty legislators from the remainder of Oregon voted two-to-one against the legislation (nine-yes, twenty-one-no). ${ }^{28}$

Senate Bill 100, as finally passed by the Oregon Legislature, authorized the establishment of a Department of Land Conservation and Development and a Land Conservation and Development Commission (LCDC) appointed by the Governor. The Department included a professional staff to serve the Commission. The LCDC, a seven-member group, was charged with developing statewide goals, guidelines, model ordinances, and an inventory on land use. It also was charged with the designation of "activities of statewide significance" and the subsequent issuance of permits for such açtivities. The LCDC was responsible for promoting strong citizen participation in the Oregon growth management process, probably stronger than any comparable effort in the nation. Furthermore, LCDC had the responsibility of reviewing and approving the comprehensive plans of local governments to conform to the goals and guidelines that it was empowered to spell out, and of coordinating all state agency land use planning.

The role of local government in the legislation was strong, especially for counties. The implementation of the objectives of the land use law relied heavily on the development of county and city comprehensive plans, within the framework of the state goals and guidelines. A procedure was provided by which counties in most areas and a regional government in the Portland area evaluated the comprehensive plans of the cities and special districts. Should these plans not conform with state goals and guidelines, the LCDC had the authority to align the plans with state goals and guidelines. The LCDC was empowered to act for any city, county, or special district that failed to do so, and a mechanism was provided for charging local governments for the cost of such action. ${ }^{29}$

\section{B. The Politics of Implementation of}

State Land and Growth Management Initiatives

The major features of the implementation record to date for each state will be analyzed now. This Section will also assess briefly the continuing role and involvement of the executive branch, the legislative branch, major pres-

28. C.E. LitTle, supra note 23 , at 30-3I.

29. Oregon Land Use Law, supra note 24. For an analysis of the law, see 1 LOCAL GOvERNment Relations Division Executive Department \& Oregon State University Extension Service, Land Use Legislation: Analysis (1974). The first and second volumes of this publication, which contain the actual text of Senate Bill 100 and that of all related land use legislation, are an invaluable documentary source in tracing the land use development initiative in Oregon. 
sure groups and the courts. Finally, an overall assessment of the level of political support for the implementation effort will be included. ${ }^{30}$

\section{The Politics of Implementation}

a. Florida

Three "areas of critical state concern" have been designated under Florida's land use law. Two areas-the Big Cypress Swamp and the Green Swamp-consist of largely undeveloped natural areas where the limitation and control of development are essential to protect vital water resource values. The third area-the Florida Keys-is more complex and involves intense existing and continued urban pressures on a fragile biological environment unique in the nation. In all three areas, special state criteria for control of development have been announced, local governments have produced land use regulations that conform with the state criteria, and the new regulations are in place and being enforced.

Over 200 developments of regional impact (DRIs) were filed in Florida from July 1973 to July 1975, with the economic recession bringing about a sharp drop in DRIs in the second year. Most projects involved proposals for large, planned-unit housing developments. Most survived the regional review process and received development orders from local governments, though often with major conditions, especially in the land and water resource areas, attached. A total of twenty-eight appeals were taken during the first two years of the Act, most initiated by regional planning councils dissatisfied with local government consideration of regional impacts. In a landmark case, involving county approval of a large housing project, the Land and Water Adjudicatory Commission overruled the county approval and voided the development order. $^{31}$

\section{b. California}

During the 1973-1976 period, after passage of the 1972 Coastal Act,

30. Space limitations restrict this treatment to a summary analysis. Further aspects of the implementation effort are included in Section $\mathrm{V}$ below.

31. J.C. Nicholas \& C. Crawford, Areas of Critical Environmental Concern: A Case Study (paper presented at the Southern Regional Science Ass'n, Richmond, Va., Apr. 1976); Division of State Planning, Bureau of Land and Water Management, Developments of Regional ImPact: A Summary Report for the. First Year July 1, 1973 through June 30, 1974 (1974), and subsequent updates. See also J.M. DeGrove, Strengthening the Role of Local Governments in the Development of Growth Policy: The Case of Florida (paper prepared for the Southern Political Science Ass'n, New Orleans, La., Nov. 7-9, 1974); L. Stepanchak, The DRI Process: A Study of Local Government Response in Broward County (1976) (unpublished thesis, Florida Atlantic University, available from the FAU/FIU Joint Center for Environmental and Urban Problems, 1515 W. Commercial Blvd., Ft. Lauderdale, Fla. 33309); and G.W. Griffith, Jr., Planning without Regulating: Troubled Path of the DRI Regional Development Condition (1974) (unpublished thesis, Florida Atlantic University, available from the FAU/FIU Joint Center for Environmental and Urban Problems, 1515 W. Commercial Blvd., Ft. Lauderdale, Fla. 33309). 
California Coastal Commissions considered 18,000 permit applications and claims of exemptions. Most were approved routinely, but some were highly controversial, involving such critical issues as beach access, density and growth, and the protection of prime agricultural land. An assessment of the exercise of the permitting portion of Proposition 20 yields the generalization that the implementation process was carried out in a fair and effective way and was used to protect coastal resources as envisaged in Proposition 20. ${ }^{32}$

The second major component required by the 1972 Coastal Act required the state and regional Coastal Commissions to develop a new coastal planning and management program for submission to the 1976 California Legislature. The most striking feature of the planning effort was the degree to which the permitting process raised important public policy issues that were reflected in the plan. Submission of the plan to the 1976 California Legislature occurred after an economic recession, Watergate, and the energy crisis, and thus involved an effort to pass a major piece of land and growth management legislation in a more negative political environment than had been the case in 1972. After a sharp political struggle, the 1976 Coastal Act was passed, and for the first time the California legislature had passed a coastal bill.

The new legislation was the product of a tense period of negotiation and compromise in which environmentalists, local government representarives, and private sector forces negotiated to reach agreement on several key issues that eventually spelled success in passing the legislation. Giving major new authority to local governments was perhaps the single, most significant change from the 1972 Coastal Act. The new law retained a State Commission, but shifted most planning and management authority to the sixty-eight cities and counties along California's coast. Local governments had to prepare Local Coastal Programs (LCPs) and submit them to the State Commission for approval. Once the plans were approved, local governments became the key implementation level, although limited state control was maintained. ${ }^{33}$ The subject areas covered by the permitting process were generally the same as under Proposition 20: 1,000 yards inland from the mean high water line. However, a number of important bulges went inland as much as ten miles and in some cases covered several miles of coastline. Furthermore, the State Commission would continue to have permitting power in certain sensitive environmental areas.

In sum, the result marked a considerable victory for local governments in their demand to be brought back into the coastal planning and regulation process and a substantial shift in attitude by environmental groups in allowing local governments a major role in the planning and implementation effort.

32. R.G. HeAly, supra note 20, at 64-102; Douglas \& Petrillo, supra note 20, at 199-212, 218.

33. For an excellent review of the politics of passage of the 1976 law, as well as its content, see California Research, State Coastal Report 4 (Aug.-Sept. 1976). 
The key to this shift in attitude lay in the fact that many environmentalists had come to view local government in a different light over the four year period from 1972 to 1976. Many environmentalists had been elected to local governments in California; and thus, were more comfortable with a larger role for local government in 1976 than in $1972 .^{34}$

\section{c. Oregon}

The heart of the implementation process in Oregon involves the preparation of Comprehensive Plans by local governments within the framework of state goals and guidelines established by the State Land Conservation and Development Commission. Once in place, these local plans are binding on special districts, state agencies, federal agencies to the extent possible, and on local governments themselves. The process has moved more slowly than anticipated. In spite of substantial state grants to local governments, by 1976 only 6 of 278 local jurisdictions had addressed a statewide goal completely. Nonetheless, substantial progress has been made. The 1978 and 1979 grant process focuses on channeling funds to local governments "most likely to have plans that comply with the statewide goals within the grant period." It is anticipated that the plan-making phase will be substantially complete by the end of 1980. The shift to state grants to support effective implementation is underway. ${ }^{35}$ The Oregon effort is more comprehensive than that being attempted by any other state. The key issue emerging is how to apply the urbanization and agricultural goals to prevent urban sprawl, and thus, protect prime agricultural land. While some feel it is a mistake to put so much emphasis in the implementation process on the local comprehensive growth management plans, others feel that it is the only foundation on which to build a long-term, politically viable growth management control system. In November 1976, the law survived a repeal effort and the 1977 session of the Oregon Legislature made substantial appropriations for continued implementation efforts. ${ }^{36}$

\section{Major Support Factors}

Within the framework of the sketches of the implementation activity under the land use laws in Florida, California, and Oregon, we will now look briefly at some major support components of the implementation effort. In

34. Interview with Janet Adams, Director, California Coastal Alliance, in San Francisco (Nov. $29,1976)$.

35. Land Conservation and Development Commission, Newsletter, Oregon Lands, Vol. 1, No. I (May 1978), at 4 .

36. Interview with Arnold Cogan, former Director of the Oregon Department of Land Conservation and Development, in Portland, Ore. (Sept. 9, 1976); Cogan, Cregon Took Giant Steps Toward Sound Land Use Planning, 10 AIP NewsletTer, No. 7 (July 1975), at 10; Richmond, LCDC at the Crossroads, Thousand Friends of Oregon Newsletter (July 1977), at 2 [hereinafter cited as Richmond]. 
Florida and in Oregon there has been strong and consistent support from the governor for the effective implementation of the legislation. Governor Reubin Askew served during the entire period of Florida's land use law through 1978, and he maintained a consistent and strong posture of support for the effective implementation of the legislation. Governor Tom McCall of Oregon was a strong supporter of the legislation during his term in office; Governor Bob Straub continued that support. In California, Governor Reagan did not support the 1972 initiative, but the legislature has consistently resisted efforts to weaken the implementation process. A $\$ 5$ million appropriation was included in the original California Proposition, and supplementary funds for special legal purposes were added by the legislature. ${ }^{37}$ Governor Brown was generally supportive of the Coastal Act and was active in passing the 1976 legislation.

There was a strong consensus in all three states that sufficient dollars be provided to fund adequately the effective implementation of the land use law. Therefore, a pattern in which a strong law was passed and its effectiveness was crippled by lack of implementation dollars was not evident in these states. There was considerable frustration in all three states with the effort to build a strong professional staff. The critical issue in every case seemed to be lack of maturity and experience rather than professional expertise. The complaint that young, fresh-faced planners did not understand the political dynamics of working with either developers or local government agencies was repeated frequently. On balance, however, in none of the three cases treated here was there a substantial erosion of support from the executive branch if it had existed at the time the original law was adopted. Nor was there any hesitation on the part of governors to ask for and fight for adequate funds to implement the legislation. ${ }^{38}$

Implementation efforts in Florida, California, and Oregon sustained strong legislative support for the land use initiatives. In Florida, several amendments to the original legislation were made that tended to strengthen rather than weaken the law. For instance, in the case of "areas of critical state concern," the authority to impose interim controls, where this was clearly needed to protect critical state interests, was added after $1972 .{ }^{39}$ However, it is also true that the legislature retained added control over future developments in the law by providing that new criteria concerning the thresholds for "developments of regional impact" developed by the Division of State Planning would have to come back to the legislature for approval before they could be implemented. ${ }^{40}$ In Oregon, with strong gubernatorial support, sub-

37. Douglas \& Petrillo, supra note 20 , at 188.

38. Interview with Hector Macpherson, supra note 26.

39. Telephone inverview with James W. May, Senior Planner in charge of Developments of Regional Impact, in Tallahassee, Fla. (Oct. 6, 1977).

40. Telephone interview with Eastern Tin, Chief of the Bureau of Land and Water Management, Division of State Planning, in Tallahassee, Fla. (Oct. 20, 1977). 
stantial appropriations of more than $\$ 6$ million were made in 1974 for a twoyear period; and this financial support was repeated for the 1976-1978 biennium. Most of these dollars were used as pass-through funds to local governments to support their planning efforts. Still the appropriation was substantial and indicated strong support for the Oregon land use law. The 1977 legislature appropriated more than $\$ 10$ million for the ensuing biennium. ${ }^{41}$

Some rather interesting developments have occurred because of the evolving role of pressure groups. In Florida, it is obvious that large developers were more united in their support of the land use law in 1979 than in 1972 when only one developer supported the law. This increased support seems to be based on a preference for dealing with a more rational state level development framework, rather than being subject to the vagaries of what many developers considered extreme and irresponsible behavior by local governments intent on slowing down or even stopping growth.

Perhaps the most striking example of a support shift among major pressure groups occurred in California. In 1970 to 1972, when major efforts to pass coastal legislation through the California Legislature were made, major oil, utility, developer, and other similar private interests opposed such legislation steadfastly and strongly. When environmental groups organized, went to the people, and were successful in putting the strong Coastal Zone Management Law on the books, private interests were shocked and dismayed. A new period of realism ensued in which governmental groups, cognizant that the intiative approach was not the long run solution, sat down to negotiate with private interest groups who were attentive due to the success of Proposition 20. Ideally, California utilities, oil interests, developers, and other private groups still may have preferred not to have coastal legislation; however, in 1976 they were willing to work closely with environmental groups, to negotiate in good faith, and to come to a compromise position in which they could at least live with the legislation that was approved by the California Legislature in $1976 .{ }^{42}$

In Oregon, while no major effort was made to weaken or repeal the law in the legislature, a petition drive was successful which forced the planning and growth management law to be placed on the ballot in November 1976. A spirited campaign occurred in which major groups that had supported the legislation in 1973 generally continued to oppose repeal; this was true of the Weyerhaeuser Corporation and the Associated Industries of Oregon. However, one major pressure group that changed its position and supported repeal of the legislation was the Oregon Homebuilders Association, although the large Portland Homebuilder's group opposed repeal. The Portland group

41. Richmond, supra note 36.

42. Interview with Janet Adams, supra note 34; interview with Mike Peavey, Executive Director of the California Council for Environmental and Economic Balance, in San Francisco, Cal. (Nov. 29, 1976) 
was deeply disappointed that the housing goal had not been given more attention in the implementation effort to that date. The repeal effort was opposed strongly by environmental groups in Oregon, by the Governor, and by others. Ultimately 57 percent of the votes cast favored continuation of the law. ${ }^{43}$ A second effort to severely weaken the Oregon law occurred in the general November 1978 election. The proposed changes would have weakened greatly the state role by limiting the Land Conservation and Development Commission to a coordinating and support role. In a notable move to support the law, the Oregon Homebuilders Association opposed the effort to weaken its provisions. In the vote, the weakening effort was defeated soundly, with 60 percent of the voters opposing the changes.

Only in the Florida courts has the question of the constitutionality of a land use law threatened the implementation of that law. A 1977 District Court of Appeals ruling held that the "area of critical state concern" component of Florida's land use law involved an unconstitutional delegation of legislative power. ${ }^{44}$ That decision was appealed to the State Supreme Court, which ruled in 1978 that the "critical area" section of the law did involve an unconstitutional delegation of legislative authority. ${ }^{45}$ This action voided the "critical area" designation of two of the state's three areas: the Green Swamp and the Florida Keys. Grovernor Reubin Askew immediately called a special session of the legislature for the purpose of reenacting the "critical areas" designations to keep them in effect. This effort succeeded, but the designation was to expire July 1, 1979, forcing the pending session of the legislature to act favorably on the redesignations if they were to become permanent.

The 1979 session of the Florida Legislature approved the redesignation of the Florida Keys and the Green Swamp as "critical areas." It reinstated the process for new designations by adding legislative standards and delaying full implementation of any "critical area" designation until the legislative session following such designation could review it. Failing explicit action by the legislature rejecting the administrative designation under the new law, it remains in effect.

There have been many court cases in California, particularly concerning the grandfather clause of Proposition 20, but none has resulted in an adverse decision regarding the constitutionality of the California Coastal Act. In Oregon, the courts have played an important, but largely indirect, role in the

43. Interview with John R. Gustafson, Deputy Director of the Land Conservation and Development Department, in Salem, Ore. (Sept. 8, 1976).

44. Cross Key Waterways v. Askew, 351 So.2d 1062 (Fla. Ct. App. 1977).

45. Askew v. Cross Key Waterways (Florida Supreme Court, No. 52,251 and 52,252, Nov. 22,1978 ). For a fuller account of the events following the State Supreme Court action, see Stroud, Areas of Critical State Concern: Legislative Options Following the Cross Key Decision, in 6 FLA. ENVIRonmental and Urban Issues 4-6 (April 1979). 
implementation of the land use law through decisions that involve the nature of the zoning process at the local level.

In assessing the overall level of political support in the implementation of the land use laws in these three states, the reasonable generalization is that despite major nationwide developments that might have affected that support negatively, the level of support maintained has been surprisingly high. Since the early 1970s when most of these laws were adopted, the United States has suffered its worst recession since the 1930s. The energy crisis came along with and related to that recession. The recession involved the near collapse of the construction industry in many states, including Florida. The Watergate scandal created an atmosphere in which any expansion of governmental power was viewed with suspicion and hostility. In the face of these forces, one might have expected serious efforts to repeal one or more of these pieces of legislation. Only in Oregon has that been the case and there it took place not in the legislature, but through citizen initative. Two efforts to repeal or to drastically weaken the law were beaten back by solid majorities. ${ }^{46}$

\section{IV}

\section{The Politics of State-Local Relations in Recent State Land and Growth Management Initiatives}

The basis for political support by environmental groups of all of the land use laws analyzed in this paper included a substantial and deep-rooted distrust of the willingness and ability of local government to address realistically the problems of land and growth management. Efforts to adopt legislation that would mandate direct action by state governments, often entirely bypassing local governments as participants in the new land and growth management process reflected this distrust, held widely by environmental groups as well as others. Florida was the only state where this strong effort to bypass local governments was not an element of consideration.

\section{A. California}

In California, in the 1970 to 1972 period, when major efforts were being made to pass a land use law through the California Legislature, there was a strong and long-standing distrust of local government by environmental groups. This distrust was the basis for a coastal zone management plan draft that focused mainly on a new state commission and regional agencies for the implementation of a coastal management plan, largely bypassing local governments. In the fight to pass legislation in this period, environmental groups offered somewhat reluctantly some concessions in the direction of a stronger

46. Fasano v. Board of Comm'rs, 264 Or. 574, 507 P.2d 23 (1973). See also Stacey, Court Appeals Limits Fasano, Thousand Friends of Oregon Newsletter (Jan. 1977), at 2; C. Gassaway, Oregon Plans the Land: A Guide to the 1973-1974 Land Use Law 20-23 (1974). 
role for local government. When these negotiations failed, partly because of a refusal by private sector interests to enter into negotiations and give any support to a coastal zone management program, environmental groups turned back to their original preference and succeeded in bringing about the adoption of a land use law that bypassed local governments. Thus, the state and regional commissions set up under California's Proposition 20, while they included local government representation on the regional commissions and potential representation on the state commission, did not include any direct role for local government in either the planning or the implementation of the new law for managing the coast.

The shock of the success of the California Coastal Alliance and its supporters in bringing about a strong coastal management law through citizen initiative produced a climate in California in which local governments and private sector interests were willing to come to the bargaining table in an effort to work out a long-range coastal management program in which local governments would be direct participants.

The reasons for the willingness of the environmental groups in California, moving from a definite base of strength, to agree to a new and much stronger role for local government are several, and no neat explanation for this willingness can be given. Perhaps as much as anything else, the political climate at the local government level changed substantially between 1970 and 1976. The strengthening of the environmental movement in the state was reflected in county and city council elections, and particularly city elections. As mentioned earlier, many of the same environmentalists who were fighting for a strong coastal management program in California also ran and were elected to city councils and county boards of supervisors. As a result, environmentalists were willing to take a chance with local government in order to attempt to build solid, long-term support for a coastal planning and management program. ${ }^{47}$

In the effort to pass a coastal management bill in California, the concessions by environmentalists in bringing local government into a central position in implementing the new law resulted in the state League of Cities' working hard to secure passage of the legislation. The counties in California, partly because of the approach of their key lobbyist in this area, never did fully support the legislation, even though many of the concessions they sought were incorporated into the law. ${ }^{48}$ The net result of the 1976 Coastal Act was not only to put local government back into the planning and implementation picture, but to give it a dominant role in the process. Simultaneously, a State Commission was retained, and that Commission was given the authority to certify city and county coastal plans in the light of state standards and criteria

47. Interview with Janet Adams, supra note 34; interview with Larry Moss, Director of the Planning and Conservation League, in Sacramento, Cal. (Dec. 3, 1976).

48. Interview with Tim Leslie, Principal Land Use Legislative Representative of the County Supervisors Association, in Sacramento, Cal. (Dec. 3, 1976). 
contained in the new legislation. Appeals of actions by local governments that allegedly do not conform to the certified plan can be taken to the State Commission; and any changes in the certified plan must be approved by the State Commission. Finally, the State Commission reserves some direct permitting power in areas of "special environmental concern." 49 What has happened in California, then, is that there has been a shift from a dominant state to a larger local government role in the effort to plan and manage California's coastline. Similar developments have occurred in other states, including Oregon.

\section{B. Oregon}

The Oregon land use law passed in 1973 (as it was originally introduced into the Oregon legislature) had included a stronger authoritative and responsible role for state and regional governments than for local governments. In the political battle to pass the law, key compromises had the net effect of strengthening local governments' role while reducing the strength of the state and regional roles. The decision to remove regional governments as the integrative unit at the local level was a victory for cities and counties in Oregon.

The Association of Oregon Counties was active and influential in the original draft and the subsequent implementation of the land use law and counties have been consistently strong supporters of the law. Cities, on the other hand, have felt that they have been left out of the process, and many (particularly the smaller Oregon cities) have been hostile to the land use law. It should be pointed out, however, that many larger cities have continued to support the legislation. While regional governments in general were denied a leading role in the planning and implementing process, special 1973 legislation created a mandatory council of governments for the metropolitan Portland area. Thus, a regional level of government is the key integrative unit for Oregon's growth management law in a metropolitan area containing over 40 percent of the state population. Furthermore, flexible legislation allows the regional level in other metropolitan areas to act as the integrative unit if local governments wish them to do so. This authority has been utilized in several metropolitan areas. ${ }^{50}$

The other major compromise that got the land use bill through the legislature substantially decreased the power of the state and thus increased the power of local governments. That compromise involved deleting from the proposed legislation the power of the Land Conservation and Development Commission (LCDC) to designate "areas of critical state concern" and to adopt

49. Id.; California Research, supra note 33, at 9-11; California Coastal Commission, Local Coastal Program Manual (July 22, 1977).

50. See ORS 197.190 for the authority for using regional agencies as the coordinating unit. SB 769 (1979 Or. Laws ch. 862) provides the statutory basis for the mandatory regional role in the Portland area. CRAG subsequently was absorbed by a new regional agency, the Metropolitan Service District, which assumed the planning and growth management responsibilities of CRAG. See ORS 268.010-.990 (1977) 
a state permitting system for those areas. Resistance by both private sectors and local governments to this particular provision led to it being removed from the legislation. What was left was the authority for the LCDC to recommend "areas of critical state concern" to the legislature, but not to act until the Oregon legislature approved the recommended designation.

In evaluating the politics of the implementation of Oregon's land use law in terms of the allocation of authority and responsibility between the state and local levels, it is clear that the LCDC has made every effort to implement the law so that local government will be involved to the ultimate possible extent. The motivation for this approach has been twofold. First, some have felt that political support for Oregon's land use law could not be sustained unless local governments could be brought into the implementation effort, facilitating their continuing support of the state legislative effort. Secondly, there was a feeling that heavy local government involvement would be the best approach from both a political support and a program implementation perspective.

Senate Bill 100 reserved the right for the LCDC to designate "activities of statewide significance" and to carry out direct state permitting in those areas. No such designation and permitting has been carried out by that state authority, and none seems forthcoming in the near future. The LCDC's failure to take advantage of its authority to recommend "areas of critical state concern" to the legislature has been noted above. Finally, Oregon's approach to coastal zone management is illustrative of a consistent effort to give local governments the largest possible role in the implementation process. It would have been possible to recommend key coastal "areas of critical state concern," to designate "activities of statewide significance" in the coastal zone, and generally to assure a stronger direct state role in putting Oregon's coastal planning and management program into operation. That approach was not taken. Instead, four new goals were added to the fourteen original ones that guide local governments in developing their "comprehensive land use plan." Thus, with regard to planning and management on the coast, the central focus is on the development of local "comprehensive land use plans" within the framework of state goals and guidelines. This part of the act gives local governments the largest role in shaping land and growth management in the state.

State environmental groups have not always been enthusiastic about the LCDC's approach in implementing the law so that the role of local governments would be enhanced to the maximum possible extent. The Thousand Friends of Oregon has constantly pressured the LCDC to make certain that it asserted an appropriate state review and modification role in the local government development process of comprehensive plans. Often this key environmental group has expressed sharp dissatisfaction with the LCDC's failure to act in a timely and effective way to see that priorities were set, that key urban boundary and exclusive agricultural use regulations were put into effect 
quickly, and that the state in general carried out its supervisory and amendatory role as comprehensive plans were implemented.

The watchdog role of the Thousand Friends of Oregon seems to have been effective in striking the balance between a strong focus on local government, while balancing local initiative and protection of the state's growth and land use interest. It is indeed a delicate political balancing act. Too much initiative by the LCDC could undermine support for Oregon's growth management law to the extent that it would face repeal efforts, which ultimately might succeed. Too little attention to a strong state role could result in the shell but not the substance of a comprehensive state-local land and growth management system. Thus far, Oregon has negotiated these political rapids with extraordinary success, and reasonable optimism suggests that a strong, but well balanced program will emerge gradually as the local governments complete and implement their comprehensive plans.

\section{Florida}

The allocation of responsibility for land use efforts between the state and local level in Florida stands in contrast to the experience in California and Oregon. A strong focus on keeping most land use decisions at the local level existed from the very beginning. The model that Florida used for this approach in drafting its land use legislation was that of the American Law Institute's Model Land Development Code draft. The two major thrusts of Florida's land use law, "developments of regional impact," (DRIs) and "areas of critical state concern," left the ultimate implementation of land use controls to the local level. However, within these two categories an important state role was included. On the one hand, DRIs approved by local governments that do not, in the view of either the Division of State Planning or the appropriate reviewing regional planning council, faithfully reflect important state and regional interests, may be appealed to the state level. Such local actions are subject to being overridden by the Land and Water Adjudicatory Commission, consisting of the Governor and six additional elected cabinet members.

The prerogative lies clearly with the state in designating "areas of critical state concern," in drawing state standards and criteria indicating special treatment, and in reviewing and, if necessary, in requiring the modification of local land use efforts to protect state and regional interests adequately. Therefore, while local government retains the ultimate role, there is a possibility of a state reversal of local actions in both the major components of the law. Local governments neither strongly supported nor strongly opposed the passage of the 1972 Land Management Act. Apparently it was felt by the leadership in both city and county organizations that should the legislation pass, it would work without serious difficulty.

In assessing the Florida implementation effort, a fairly sharp distinction 
must be made between the effort that relies largely on local governments and private developers for initiative and continuing implementation-the DRI process-and the part that is initiated at the state level, the "area of critical state concern" process. With regard to DRIs, the state regulations spelled out quantitative criteria for determining whether a project would fall into the DRI category. Subsequently, local governments were placed in control of the process, with an important review and evaluation role for Florida's regional planning councils and, to a lesser degree, its regional water management districts. The process, insofar as it can be evaluated to date, seems to have worked rather well. It has not sparked large-scale friction between and among local governments, regional governments, and the state, and in general, seems to have worked well both from the state and the local government points of view. It is difficult to assess how well it will stand up under a period of sustained and strong growth pressures. The full implementation of the DRI process in Florida coincided roughly with the collapse of the construction industry. That ailing industry is beginning to be built up again in Florida. The next several years will test how effectively DRIs can perform in the face of renewed growth pressures. An added element of uncertainty was introduced into the DRI process in 1977 when the First District Court of Appeals ruled that the threshold criteria developed by the state land planning agency with the help of a special study committee (and subsequently approved by the legislature) were not preemptive in determining whether a development was or was not one of regional impact. ${ }^{51}$ This decision means that a project meeting the criteria might nevertheless be certified by the state land planning agency not to be a development of regional impact because no such impacts were present, while one below the thresholds might be judged a DRI because of the presence of identifiable regional impacts. Thus the flexibility (and uncertainty) introduced by this ruling could change the implementation of this section of the law and its impact on local governments in ways that have not become evident.

An initial flurry of activity at the state level, resulting in the designation of three "areas of critical state concern," stirred a great deal of political controversy and hostility between local governments and the state. In every case where a critical area designation has taken place, there has been a substantial amount of strong local resistance to and resentment of the state role in the process. The "areas of critical state concern" component of the law came to a virtual standstill after 1976 partly as a result of the resistance, partly as a result of an apparent lack of enthusiasm among certain sectors of state government for designating additional "critical" areas and partly as a response to

51. General Development Corporation v. Division of State Planning, 353 So. 2d 1199 (Fla. Ct. App. 1977). 
the drastic slowdown of growth in Florida. The above noted adverse ruling ${ }^{52}$ simply added to the mitigating forces against the formal designation of new areas. Thus no new areas have been designated since the Florida Keys regulations were put into operation in 1976. The Bureau of Land and Water Management within the state land planning agency has devoted its efforts since 1976 to organizing and staffing voluntary state-local efforts at solving problems that, if left unattended, would eventually require a formal designation. ${ }^{53}$

It is ironic that Florida's land use law component depending most heavily and more directly on local government, the DRI process, seems to be moving forward in the implementation process more effectively than that component that depends largely on state initiative to bring new critical areas under consideration and to bring about ultimate designation and regulation of such areas. Environmental groups and others in Florida began to express strong discontent with what many of them considered to be "foot dragging" at the state level in land management in general, and in particular with regard to the "area of critical state concern" process. ${ }^{54}$ In Florida, the allocation of authority between state and local levels was developed in the implementation process similarly to the way it was contemplated in the original legislation. Local governments are still supportive of the legislation. The state role is; if anything, weaker than originally envisaged in the Land Management Act, but this may be due in part to strong resistance from the local level to the three "areas of critical state concern" that have been designated, and even that resistance may be shifting to a more cooperative state-local effort in these areas.

A further complication in implementing the Land Management Act was 1975 passage of the Local Government Comprehensive Planning Act. ${ }^{55}$ This law mandated the development of a comprehensive plan by every city and county government in Florida, thus filling a void in the original land use law, which had the potential for exempting cities and counties from the Land Management Act which had no planning and zoning legislation in effect. The loophole has been eliminated, effective after 1979. On the other hand, cities and counties (especially cities) have been resentful of the imposition of the state mandate without state funds to support compliance with the required comprehensive planning. In spite of this, the planning process is going forward, with most local governments moving to comply with the state regulation.

52. See note 44 supra.

53. See Charlotte Harbor: A Florida Resource, Division of State Planning, Department of Administration (1978) DSP-BLWM-39-78, and The Appalachacola River and Bay System: A Florida Resource, Division of State Planning, Department of Administration (April 1977) DSPBLWM-5-77.

54. Interview with Hal Scott, Director of the Florida Audubon Society, in Orlando, Fla. (Oct. 25, 1977).

55. FLA. STAT. $\S \S 163.3161-163.3211$ (1975). 


\section{Conclusion}

In summary, California, Oregon, and Florida have chosen contrasting paths to what seems to be an emerging common goal: a strong focus on local governments in the planning and implementation components of land and growth management. The initial Oregon proposals gave more power to the state level than did the final draft of the law the legislature adopted. The initial California law depended completely on the state and regional levels both to implement a permitting system and to develop a long-range plan. Only Florida had a consensus from the beginning that the bulk of the controls should be left to the local government. Yet all three states have moved away from a direct state planning and permitting role and toward placing that responsibility on local governments, within the framework of state standards and guidelines.

\section{$\mathrm{V}$ \\ The Politics of the Future in \\ Land and Growth Management}

The combination after 1973 of a severe economic recession, the fact that the national land use law did not pass, the national disillusionment following Watergate and related incidents, with expanded government regulation, the continuing anxiety over energy shortages: these and related forces have been interpreted by some as meaning that the political future of land and growth management initiatives at any level of government in our federal system is dim. While conceding that the peak of enthusiasm, including the strong political cutting edge that carried land use legislation through a number of state legislatures in rapid succession in the early 1970s, no longer describes accurately the political atmosphere, it does not seem necessary to conclude that all of the force is gone out of political support for land and growth management. For one thing, state action has continued, albeit at a slower pace, into the late 1970 s.

It is probably true, however, that proponents of land and growth management must face head-on a tendency of opponents to cast economic and environmental health as contradictory and mutually exclusive goals. If supporters of active government involvement in land and growth management concede that a strong land and growth management framework by government conflicts with a healthy economy, it will be extremely difficult to sustain political support for such programs. Each economic recession would signal new attempts to weaken land and growth management programs.

Political leaders who support growth management initiatives recognize this danger and insist that national and state economic health does not conflict with strong land and growth management programs, and that the two must go hand in hand for long-term prosperity. Governor Askew has been a consistent and leading proponent of this position. In the last two years of his 
administration (1976-78) he took an aggressive role in attempting to attract new industry to the state; at the same time, he maintained the attitude that effective environmental management programs did not conflict with a proindustry position, and that the quality of life that such land and water management implies is absolutely essential in attracting to Florida (and by implication to any state) the industry that most residents would welcome. His successor, Bob Graham, ran on a platform, among other issues, of strong economic development for the state; but Graham was also the key legislative leader in passing Florida's land management act in 1972, and as governor, he proposed and strongly supported several successful environmental programs to the 1979 legislature, including the critical area corrective legislation noted above.

The proposition that economic and environmental health do not conflict with each other is absolutely necessary to the long-term strength of land and growth management laws at all levels of government. The past record does not clearly indicate the future success of proponents of such laws in making this point in political arenas such as the Congress and state legislatures. Present data are incomplete, but instructive. There have been no major reversals to date of the land use laws adopted during the early 1970s. ${ }^{56}$ The 1976 effort in Oregon to repeal the land use law failed by a substantial margin. Another effort to cripple the law failed in 1978 by a wide margin. The 1972 California law called for readdressing the entire issue of planning and managing California's coast in the 1976 California Legislature. In 1976 environmental groups compromised with local governments and private sector interests to produce coastal planning and management legislation that seems to bode well for the future of California's coast.

The most recent, and in some ways the most revealing, measure of the continued strength of the land and growth management effort at the state level may be seen in the action of the 1979 Florida Legislature. A major revision of the Land Management Act to cure the delegation problem of the critical area section of the law, and several other major pieces of environmental legislation passed.

A companion measure to the 1972 Florida Land Management Act, the Land Conservation Act, ${ }^{57}$ provided a $\$ 200$ million fund for purchasing of environmentally endangered lands. By 1979 all but $\$ 18$ million of the original fund had been spent. In spite of a negative atmosphere produced by allegations of improper actions in some of the purchases, the Governor proposed

56. An exception may be Colorado, where the 1977 Legislature cut funds for the State Land Use Commission from some $\$ 200,000$ to about $\$ 50,000$, forcing the governor to use emergency funds to support the agency. However, strong state land use advocate Governor Richard Lamm won his race for reelection in the face of Republican efforts to defeat him, by attacking in part his land and growth management posture. Lamm carried 60 percent of the vote.

57. Land Conservation Act of 1972, FLA. STAT. ANN $\S 959.01-.07$ (West 1975). 
and the legislature approved a law providing for permanent funding for the purchase of environmentally endangered lands and for related purposes. By 1981 an annual amount of up to $\$ 20$ million will be available for earmarked severence tax sources; a lesser amount has been set aside for the next two years.

Interest group support for the needed reenactment of the critical area section of the Land Management Act is revealing in assessing continued political support for land and growth management programs in Florida. In 1972, the state Homebuilder's Association strongly opposed the act, while the State Association of County Commissioners was neutral. In 1979, the Homebuilder's group strongly supported the amendment, as did the county group. Similar support can be observed in Oregon. Thus, in the cases where there has been a "retest" in the political arena, land and growth management laws have not only survived, but in some cases they have been strengthened and have demonstrated the capacity to attract new sources of support.

Perhaps the key test for the immediate future lies in the question how active the federal government will be as a promoter of land and growth management. The test will come in the degree to which there is further implementation at the state and local. levels of coastal zone management programs that conform to the federal Coastal Zone Management $\mathrm{Act}^{58}$ guidelines. About nineteen states have received final approval by the Secretary of Commerce for their programs. ${ }^{59}$ Other states, representing all sections of the nation, are scheduled to make strong efforts in their 1979 and 1980 legislative sessions to win approval of coastal legislation implementing effective planning and management programs that will, among other things, satisfy the requirements of the federal law and thus qualify the states for generous financial grants. ${ }^{60}$

The fact that these efforts will be made indicates that federal law can encourage state action in the land and growth management field. The test of the significance of the encouragement, of course, will be in the quantity and quality of state coastal zone management programs that are enacted as a result of the effort. Furthermore, a central question in these coastal zone programs will be the same question that has figured in every state where such a program has already been considered: the allocation of power between state and local levels. In the cases examined in this article, the trend is toward a heavy reliance on the local government level within a more general frame-

\footnotetext{
58. See note 7 supra.

59. Oregon was among the first states to secure federal approval.

60. Telephone interview with Office of Coastal Zone Management, Washington, D.C. (Nov. 13, 1979). States with Coastal Zone Management Programs approved by the U.S. Dept. of Commerce are: Alabama, Alaska, California, Delaware, Hawaii, Maine, Maryland, Massachusetts, Michigan, New Jersey (Bay and Ocean Shores), North Carolina, Oregon, Rhode Island, South Carolina, Washington, Wisconson; Guam, Puerto Rico, Virgin Islands.
} 
work at the state level. It would seem that continued development of this pattern gives the greatest hope for strong sustained political support for these programs into the future.

In assessing again the question whether the land and growth management movement can command substantial political support over the long haul, it must be remembered that the environmental groups so active in the late sixties and early seventies have not faded away. In many states, with California and Florida as leading examples, environmental groups have matured politically and their leadership is an important element of the power structure at both state and local levels. Thus the basis for long-term political support exists. If the support of local government and private sector groups, such as Homebuilders, can be added to this base, and if the concern for quality of life (including but not restricted to narrow environmental concerns) continues to warrant strong popular support, then the political future of land and growth management programs seems bright. The testing ground for the immediate future will be attempts to establish other coastal zone management programs and this effort will, in turn, have great significance for broader land and growth management programs. Finally, it will be the crucial testing arena for the continuing impact of land and growth laws on the distribution of power in the federal system. 